\title{
Cooperative Learning as a Strategy in Solving Word Problems in Mathematics
}

\author{
Cybele Grace P. Aninion, Dr. Emybel M. Alegre \\ College of Education, Caraga State University \\ DOI: 10.29322/IJSRP.11.10.2021.p11848 \\ http://dx.doi.org/10.29322/IJSRP.11.10.2021.p11848
}

\begin{abstract}
This study analyzes the attitude of the students in Agusan National High School (ANHS) towards cooperative learning as a strategy in solving word problems in mathematics. In answering the objectives this study used a twenty-one-item survey questionnaire based on the five components of cooperative learning and another five items for the word problem. The study has a null hypothesis stating that there is no significant relationship between cooperative learning and mathematics performance of the students and there is no significant difference in the mathematics performance of the students before and after the cooperative learning is applied. It is concluded that the grade 10 students got a very high level of attitude in positive interdependence and social skills, while promotive face-to-face interaction, individual accountability, and group processing only got a high level of attitude.
\end{abstract}

Index Terms- Cooperative Learning, Mathematics Performance, Word problems

\section{INTRODUCTION}

$\mathrm{R}$ esearch on cooperative learning was scarce before the 1970s, however, since this date, the amount and the quality of research on cooperative learning have greatly accelerated given its great appraisal and positive effects on education (Slavin, 1996). Numerous studies have stressed the positive effects that cooperative learning has on academic achievement (Jensen \& Moore, 2002; Gillies \& Ashman, 1996; Rojas-Drummond, Hernandez, Velez, \& Villagran, 1998; FergusonPatrick, 2007) and social interaction (Jordan \& Le Métais, 1997; Vasileiadou, 2009; Choi, Johnson, \& Johnson, 2011) among other outcomes. Cooperative learning has become such a widely used instructional procedure in all educational contexts that it is even difficult to find instructional material that does not refer to this methodology (Johnson, Johnson \& Stanne, 2000).

As of 2009 more than 1,200 research studies had been conducted on cooperative learning, and a significant amount of those studies focused on the effects of cooperative learning on achievement in comparison to more traditional, individualistic, or competitive instructional methods (Johnson \& Johnson, 2009). High school students perform better through cooperative learning than from a teacher-centered approach (Gillies, 2016). Cooperative learning also enables students to effectively accomplish practical procedures, perform valid research hence making it easier for the educators to manage student's learning. In addition, CL encourages the students to effectively contribute towards the problems solving leading to a better understanding of the subjects (Davidson \& Major, 2014). Cooperative learning could be presumed to be a better approach that could benefit students in the Philippines, only if it could be implemented properly.

This study was conducted to determine if cooperative learning is one of the best strategies if not, a highly recommended one in solving word problems in mathematics.

This study hopefully contributed to the improvement of education in mathematics. This research encouraged the faculty administration and also the teachers to be drawn to this method of teaching a student-centered approach and to adapt it as an effective teaching strategy that will benefit the students. The outcomes to be considered are the improvement of students' abilities in terms of positive interdependence, promotive face-to-face interaction, individual accountability, social skills, and group processing. The participants of the study were Grade 10 students of Agusan National High School (ANHS). Among the 1021 students, 105 students served as the participants of the study. The researchers used a survey questionnaire for the survey as observation and gathering of data among the participants.

\section{THEORETICAL AND CONCEPTUAL FRAMEWORK}

This study does not just follow from one single theoretical perspective, but it mainly covered the theories of Deutsch, Lewin, Piaget, Vygotsky, Dewey, Springer, Millis, and Johnson.

Scholars within the cooperative learning literature often refer to such disparate fields as philosophy of education, social psychology, cognitive psychology, and behaviorism and educational theorists such as Morton Deutsch, Kurt Lewin, Jean Piaget, Lev Vygotsky, and John Dewey (Roseth et al., 2008; Springer et al., 1999; Millis, 2010; Johnson \& Johnson, 1989). While the grounding in so many fields of psychology is seen as the strength of cooperative learning (Johnson \& Johnson, 1989), it naturally causes some confusion as to whether one can speak of a cooperative learning theory as such. Springer et al. (1999) distinguished between motivational, affective, and cognitive perspectives on cooperative learning. Dansereau and Johnson (1994) distinguished between social-behavioral perspectives and cognitive developmental perspectives. Slavin (1994) also distinguished between motivational and cognitive perspectives on cooperative learning but later distinguished between motivational, social cohesion, cognitive, and developmental perspectives (Slavin, 1996) as shown in Table 1. 
Table 1. Theoretical perspectives on cooperative learning

Theoretical perspective

Motivational (behavioral) perspectives

Social cohesion perspectives

Developmental perspectives

Cognitive elaboration perspectives

\section{Conceptual Framework}

Cooperative learning structures seek to provide higher student engagement in the classroom. Cooperative learning is not just placing students together in small groups. Small-group instruction in the loosest sense is physically arranging students in groups as instruction proceeds. However, a stricter sense of small group instruction refers to using specific instructional strategies while students are placed into small groups for learning (Abrami, Lou, Chambers, Poulsen, \& Spence, 2000). Cooperative learning would lean toward a stricter sense. Cooperative learning is more than just group work. It is structured to maximize learning and communication within the group (Kagan \& Kagan, 4 2009). A cooperative learning group is also seen as a group that works together to accomplish a common learning goal and regularly checks for progress and performance toward a learning goal. The

\section{Assumptions}

If students are rewarded for cooperation or if their achievement is in part contingent upon the achievement of fellow group members, they will help each other to maximize their outcome.

If students value peers and are dependent on each other they will be likely to help one another to reach their goals.

Interaction with peers is likely to result in cognitive disequilibrium. Inadequate reasoning will be exposed, and higher-quality understandings will emerge.

Retention of knowledge in memory needs cognitive restructuring. Explaining material to someone else is an effective means of elaborating. outcome is that everyone in the group gained academic performance (Johnson \& Johnson, 1999).

These were five elements that distinguish cooperative learning. Positive interdependence refers to the sense of the group succeeding or failing together. Face-to-face promotive interaction requires students to help each other learn as well as to applaud the success and effort of their team members. The individual and group accountability measures indicate the importance of each group member making contributions to the team. Interpersonal and small group skills require communication, trust, and team building. Finally, group processing is referred to as groups reflecting on their progress toward a common goal (Marzano, Pickering \& Pollock, 2001). 


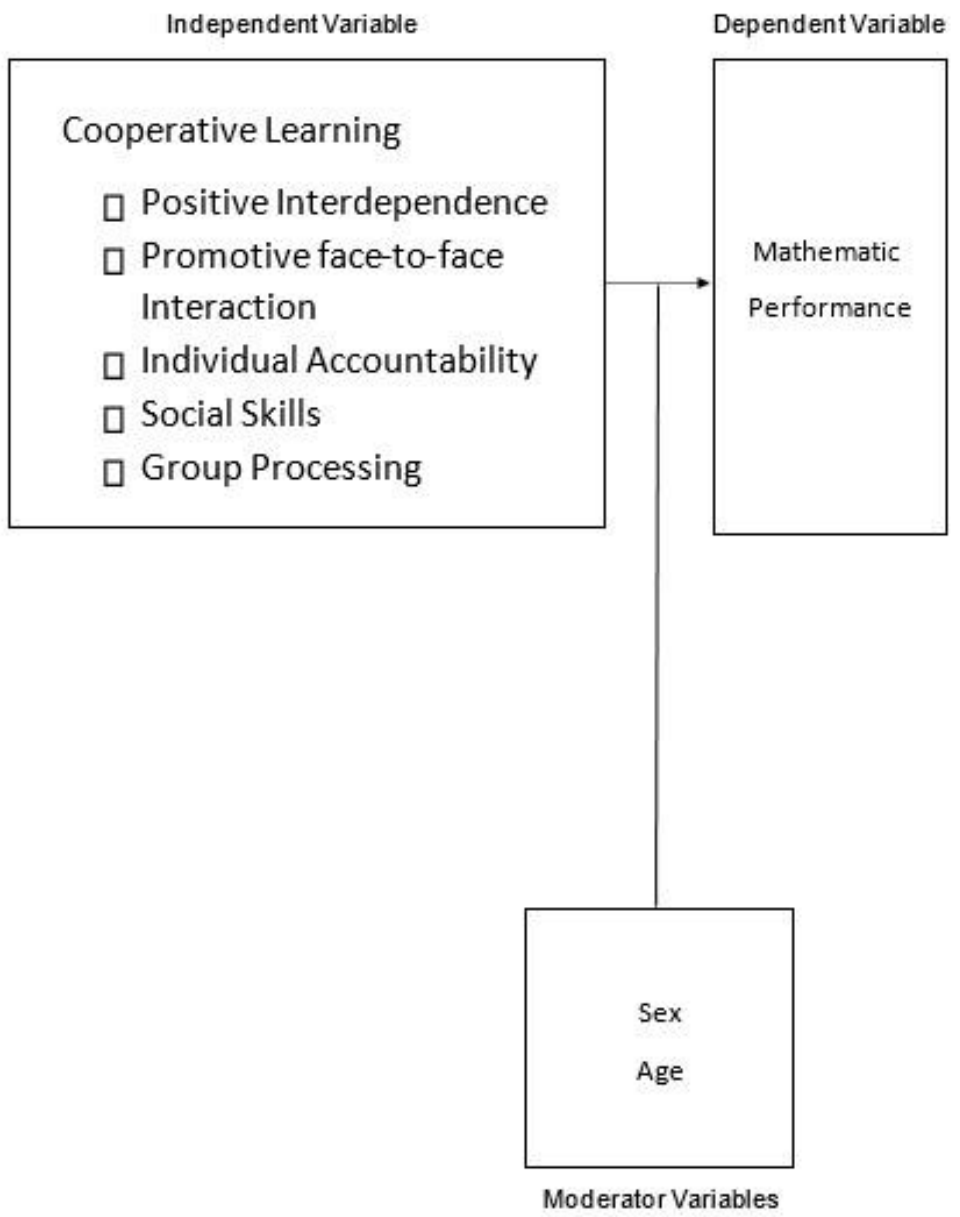

Figure 1. Flow chart of the study

\section{ReSEARCh Methodology}

This study employed the descriptive survey method of research. It was descriptive because it provided pieces of information on the students' demographic profiles. Moreover, it also determined whether relationships and differences is existing between the set of variables in the study. The questionnaire served as the main data-gathering instrument to sought answers to the problems in the study.

This study was conducted in Agusan National High School (ANHS), Division of Butuan City. It is one of the largest secondary public schools in Caraga Region. It is located at A.D. Curato Street, Butuan City, near the National Highway. The school can be reached by riding multicab or a motorcycle. It is 2 kilometers away from the city proper and it will just take 5 minutes to travel.

The population of the study was the Grade 10 students of Agusan National High School that were enrolled during the academic year 2017-2018. There were 1021 students and 105 of them served as participants of the study.

Table 1. The Distribution of population as respondents of the study

Population

Female Male

$69 \quad 36 \quad 105$

Total
To get the number of participants in the study, the researchers chose the Grade 10 students. The selection was done through stratified random sampling and only $10 \%$ of the students served as the participants.
The study used a survey questionnaire as its research instrument. This was self-constructed and was composed of three (3) parts. Part 1 showed the demographic profile of the students, part 2 showed the students' attitude towards cooperative learning that included the positive interdependence, promotive face-to-face 
interaction, individual accountability, social skills, group processing, and part 3 showed the sets of word problems, five (5) items, specifically. The researchers used an appropriate scaling for the given questions to ensure student's reliable responses.

The researchers self-constructed the survey and were validated by two (2) experts and undergone pilot testing at Carmen National High School and Nasipit National Vocational School that covered 60 participants.

The distribution of survey questionnaires relied upon the validation of experts. After which, it underwent pilot testing at Carmen National High School and Nasipit National Vocational School to make sure that it was reliable for distribution. The researchers primarily wrote a letter of permission for the distribution of survey questionnaires. After the letter is approved, the researchers then asked the mathematics teacher's consent to survey her class.

The researchers surveyed by distributing the questionnaires. The questionnaires were retrieved right after the participants have answered all items. The same questionnaire was conducted the next week with the same respondents. But this time, it was answered individually.

The data gathered were analyzed according to the study objectives. After gathering the data, the researchers utilized the frequency, weighted mean, and p-value for the analysis of data, interpretation purposes, and conclusions.

\section{Scoring and Quantification of Data}

The following variables were scored as follows:

\begin{tabular}{lll}
\hline Scale & Verbal Description & Interpretation \\
\hline 5 & Always & Very High \\
4 & Almost Always & High \\
3 & Often & Average \\
2 & Seldom & Below Average \\
1 & Never & Low \\
\hline
\end{tabular}

The researchers used these statistical tools in the analysis and interpretation of data:

1. frequency for the description of the participants' demographic profile;

2. Weighted mean for the students' perception towards cooperative learning and students' scores in word problems, by individual and by group; and 3. p-value for the significant relationship between students' attitude towards cooperative learning and for the significant difference of the students' scores by group and individual.

\section{PRESENTATION, ANALYSIS AND INTERPRETATION OF DATA}

Problem 1. What is the personal profile of the students in terms of: age and gender?

Table 2. Distribution of the students' age

\begin{tabular}{lll}
\hline Age Category & Frequency & Percentage \\
\hline 15 and below & 34 & 32.4 \\
16 to 17 & 68 & 64.8 \\
18 and above & 3 & 2.9 \\
\hline Total & 105 & 100.0 \\
\hline
\end{tabular}

As shown in the above table, in terms of age, there were 105 total students in which 34 of the participants were 15 years old and below, that is $32.4 \%$, 68 were 16 to 17 years old, that is $64.8 \%$, and 3 out of 105 participants were 18 years old and above, that is $2.9 \%$. The data implied that most of the participants were 16 to 17 years old.

Table 3. Distribution of the students' gender

\begin{tabular}{lll}
\hline Gender & Frequency & Percent \\
\hline Female & 69 & 65.7 \\
Male & 36 & 34.3 \\
\hline Total & 105 & 100.0 \\
\hline
\end{tabular}


Table 3 shows the profile of the participants in terms of gender, out of 105 students, 69 of them were female, that is $65.7 \%$, and 36 were male, that is $34.3 \%$. This implied that the majority of the students were female.

Problem 2. What is the attitude of the students about cooperative learning in terms of positive interdependence, promotive face-to-face interaction, individual accountability, social skills, and group processing?

Scaling

\begin{tabular}{lll}
\hline Range & Verbal Description & Interpretation \\
\hline $1.000-1.800$ & Never & Low \\
$1.801-2.600$ & Seldom & Below Average \\
$2.601-3.400$ & Often & Average \\
$3.401-4.200$ & Almost Always & High \\
$4.201-5.000$ & Always & Very High \\
\hline
\end{tabular}

Table 4. Students' Attitude towards Cooperative Learning concerning Positive Interdependence

\begin{tabular}{lllll}
\hline \multicolumn{1}{c}{ Particular $\quad$ Mean Score } & & & Remark & Interpretation \\
\hline 1. I consider my groupmates' ideas. & 4.5619 & & Always & Very High \\
\hline 2. I participate in brainstorming done by & $4.2667 \quad$ the & group. & Always & Very High \\
& & & & \\
\hline 3. I am responsible for every task I am & 4.0476 assigned. & Almost & High
\end{tabular}

\section{\begin{tabular}{llll}
\hline OVER-ALL & 4.2920 & Always & Very High
\end{tabular}}

Table 4 shows that the participants got a very high level in terms of positive interdependence, having an over-all mean score of 4.2920. This implies that the students always perceive that working together is individually and collectively beneficial, and success depends on the participation of all the members.

Table 5. Students' Attitude towards Cooperative Learning with respect to Promotive Face-to-Face Interaction

\begin{tabular}{|c|c|c|c|c|}
\hline Particular & \multicolumn{2}{|l|}{ Mean Score } & \multirow{2}{*}{$\begin{array}{l}\text { Remark } \\
\text { Always }\end{array}$} & \multirow{2}{*}{$\begin{array}{l}\text { Interpretation } \\
\text { Very High }\end{array}$} \\
\hline $\begin{array}{l}1 . \quad \mathrm{I} \\
\text { groupmates' feelings. }\end{array}$ & considerate & 4.3905 & & \\
\hline \multicolumn{3}{|c|}{$\begin{array}{l}\text { 2. I deliver my opinion well. } \\
4.0000\end{array}$} & Almost Always & High \\
\hline \multicolumn{3}{|c|}{$\begin{array}{l}\text { 3. I interact with my groupmates to make } \\
4.3143 \text { them feel they are part of the group. }\end{array}$} & Always & Very High \\
\hline \multicolumn{3}{|c|}{$\begin{array}{l}\text { 4. I disapprove of someone's opinion in a } \\
\text { constructive way. } 3.8365\end{array}$} & Almost Always & High \\
\hline \multicolumn{2}{|c|}{$\begin{array}{l}\text { 5. I don't force my groupmates to contribute } 3.7524 \\
\text { group. }\end{array}$} & something in the & $\begin{array}{l}\text { Almost } \\
\text { Always }\end{array}$ & High \\
\hline \multicolumn{3}{|c|}{ OVER-ALL $\quad 4.0571$} & $\begin{array}{l}\text { Almost } \\
\text { Always }\end{array}$ & High \\
\hline
\end{tabular}

As shown in the above table, particulars 1 and 3 got a very high level in terms of promotive face-to-face interaction. Then, the remaining particulars got a high level of the mean score.

This implies that the students sometimes facilitate learning and contributions by each other. 
Table 6. Students' Attitude towards Cooperative Learning concerning Individual Accountability

\begin{tabular}{|c|c|c|c|}
\hline Particular & Mean Score & Remark & Interpretation \\
\hline $\begin{array}{l}\text { 1. I consider my groupmates' ideas but what matters } \\
\text { most is my contribution to the group. }\end{array}$ & 3.7429 & $\begin{array}{l}\text { Almost } \\
\text { Always }\end{array}$ & High \\
\hline $\begin{array}{l}\text { 2. My performance, even when I am in a group, is } \\
\text { what will shape my grade. }\end{array}$ & 3.9714 & $\begin{array}{l}\text { Almost } \\
\text { Always }\end{array}$ & High \\
\hline $\begin{array}{l}\text { 3. I am concern with how well I perform the task not } \\
\text { on how well we perform the task. }\end{array}$ & & Almost & \\
\hline $\begin{array}{l}\text { 4. My assigned task is better organized when I work } \\
\text { alone. }\end{array}$ & $\begin{array}{l}3.4952 \\
3.7905\end{array}$ & $\begin{array}{l}\text { Always } \\
\text { Almost } \\
\text { Always }\end{array}$ & $\begin{array}{l}\text { High } \\
\text { High }\end{array}$ \\
\hline OVER-ALL & 3.7500 & $\begin{array}{l}\text { Almost } \\
\text { Always }\end{array}$ & High \\
\hline
\end{tabular}

The table implies that the students got a high level in terms of individual accountability, having an overall mean score of 3.7500. The perception's remark is almost always; this means that the students sometimes do not just rely on their classmates' contribution but also to theirs.

Table 7. Students' Attitude towards Cooperative Learning concerning Social Skills

\begin{tabular}{|c|c|c|c|}
\hline Particular & Mean Score & Remark & Interpretation \\
\hline 1. I willingly share $m$ & a with the group. 4.1810 & $\begin{array}{l}\text { Almost } \\
\text { Always }\end{array}$ & High \\
\hline
\end{tabular}

2. I find no hard time working with groups. 4.2095

3. Working in a group is way more comfortable 4.1619 than working alone.

4. I don't put barriers between me and my 4.1714 groupmates.

5. Working in a group is a whole lot of fun. 4.3905
Always Very High

Almost

Always

High

Almost

Always

Always $\quad$ Very High

\section{$\begin{array}{llll}\text { OVER-ALL } & 4.2229 & \text { Always } & \text { Very High }\end{array}$}

As shown in the above table, particulars 2 and 5 got a very high level in terms of social skills, having the mean score of 4.2095 and 4.3905 , respectively. Then, the remaining particulars got a high level of the mean score. This implies that the students are always comfortable with working in groups.

Table 8. Students' Attitude towards Cooperative Learning concerning Group Processing

\begin{tabular}{|c|c|c|c|}
\hline Particular & Mean Score & Remark & Interpretation \\
\hline $\begin{array}{l}\text { 1. After the group } p \\
\text { how we might impr }\end{array}$ & nce, we open up 3.9333 with each other on & $\begin{array}{l}\text { Almost } \\
\text { Always }\end{array}$ & High \\
\hline
\end{tabular}


2. Improving our performance is what we are up

to. $\quad 4.1810$

Almost

Always High

3. We take each of the member comments

to improve our next group performance, as 3.9333 well as ourselves. Almost

Always High

4. We are willing to learn brand new things to 4.4190 improve our Always performance.

In terms of group processing, as shown in the table, the participants got a 4.1167 overall mean score which implies a high level of allowing their group members to improve their work together continuously over time.

Problem 3. Is there a significant relationship between students' attitudes about cooperative learning and their mathematics performance?

Table 9. Relationship between Students' Attitude towards Cooperative Learning and their Scores in Word Problems

\begin{tabular}{|c|c|c|c|}
\hline Variables & $\begin{array}{l}\text { Pearson's } \\
\text { Correlation } \\
\text { Coefficient }\end{array}$ & Pvalue & Remark \\
\hline
\end{tabular}

\begin{tabular}{llllll}
\hline CL Attitude & and & Individual & -0.110 & 0.264 & Not Significant \\
Score in WP & & & &
\end{tabular}

$-0.141 \quad 0.152 \quad$ Not Significant

CL Attitude and Group Score in

WP

*Significant when p-value is less than 0.05 significance level; $C L=$ Cooperative Learning; WP = Word Problems

As shown in the table above, the p-value of cooperative learning attitude and individual score in word problems is 0.264 , this implies that they have no significant relationship. The same goes with a cooperative learning attitude and group score in word problems, having a p-value of 0.152 .

Problem 4. Is there a significant difference of the mathematics performance of the students before and after the cooperative learning is applied?

Table 10. Significant Difference of the Students' Scores by Group and Individual Scores

\begin{tabular}{llllll}
\hline Paired Variables & $\begin{array}{l}\text { Mean of the } \\
\text { differences }\end{array}$ & $\begin{array}{l}\text { Tstatistic Degrees of } \\
\text { Freedom }\end{array}$ & Pvalue & Remark \\
\hline $\begin{array}{l}\text { Group Score }- \\
\text { Individual Score }\end{array}$ & 5.305 & 13.780 & 104 & 0.000 & Significant
\end{tabular}

*Significant when the p-value is less than 0.05 significance level

The table shows the students' scores and individual scores in the given word problems. Having the mean of the differences of 5.305 means that the group scores are way high than the individual scores of the students. And having a p-value of 0.000 , implies that there is a significant difference between the students' scores by group and individual scores.

In addition, Nichols (1996) concluded in his study (students were assigned to either a control group that received traditional 
instruction and treatment groups that received cooperative learning instruction- an 83-item assessment was used as a pretest and posttest) that students receiving cooperative learning experienced increases in their intrinsic valuing of the learning task, self-efficacy, and learning goal orientations and their reported use of deep processing strategies.

\section{CONCLUSIONS}

Based on the findings of the study, the following conclusions were drawn:

The profile of the Grade 10 students in terms of age showed that most of the students were 16 to 17 years old and most of them were female.

The respondents got a very high level of attitude in positive interdependence and social skills, this means that the students always perceive that working together is individually and collectively beneficial, success depends on the participation of all the members; and that the students are always comfortable with working in groups. On the other hand, the remaining three elements- promotive face-to-face interaction, individual accountability, and group processing got only a high level. This implies that the students sometimes facilitate learning and contributions by each other; do not just rely on their classmates' contribution but also on theirs, and allow their group members to improve their work together continuously over time.

The study also showed that the p-value of the relationship between students' attitude towards cooperative learning and their scores in word problems by individual and by the group are 0.264 and 0.0152 , respectively, which are greater than the 0.05 significance level. Thus, the two variables don't have a significant relationship.

By looking at the participants' scores, it was clearly shown that their scores increased after the cooperative learning is applied. Hence, there is a significant difference between the students' scores by group and by an individual.

Based on the results the researchers have gathered, it is therefore proven that cooperative learning is one of the best strategies or a highly recommended one in solving word problems in mathematics.

\section{REFERENCES}

[1] Andrini, B. \& Kagan, S. (2013). Cooperative learning: A multi-structural approach. San Juan Capistrano, CA: Resources for Teachers, Inc.

[2] Davidson, N., \& O’Leary, P.W. (2000). How cooperative learning can enhance mastery Teaching: Educational Leadership. San Juan Capistrano, CA: McGraw-Hill

[3] Gillies, R. M. (2016). Cooperative Learning: Review of Research and Practice. University Park, PA: Australian Journal of Teacher Education Goodsell, A., Maher, M. \& Tinto, V.

[4] (1992). Collaborative Learning: A Sourcebook for Higher Education. University Park, PA: National Center on Postsecondary Teaching, Learning and Assessment

[5] Johnson, D., Johnson, R. \& Holubec, E. (2008). Cooperation in the classroom. Edina, MN: Interaction Book

[6] Johnson, D.W., Johnson, R.T. (1994). An overview of cooperative learning. Creativity and Collaborative Learning. Baltimore, MD: Brookes Press

[7] Johnson, D.W., Johnson, R.T. \& Smith, K.A. (2000). Active Learning: Cooperation in the college classroom. Edina, MN: Interaction

[8] Kagan, S. (2002). Cooperative learning. San Juan: Kagan Cooperative Learning

[9] New Horizons for Learning. (2005). Cooperative Learning http://www.newhorizons.org/strategies/cooperative/front_cooperative.htm

[10] Nichols, J. D. (2012). The effects of cooperative learning on student's achievement and motivation in a high school geometry class. www.eric.ed.gov

[11] Parrenas, C.S. \& Parrenas, F.Y. (2003). Cooperative learning, multicultural functioning, and student achievement. Washington, DC: The Magazine of the Graduation Management Admissions Council

[12] Slavin, R. (2005). Cooperative learning: Theory, research and practice. Englewood Cliffs, NJ: Prentice Hall

[13] Slavin, R. (1996). Research on Cooperative Learning and Achievement: What We Know, What We Need to Know. MD: Brookes Press

[14] Williams, R.B. (2007). Cooperative Learning: A Standard for High Achievement. Thousand Oaks, CA: Corwin Press

\section{AUTHORS}

First Author - Cybele Grace P. Aninion,, College of Education, Caraga State University

Second Author - Dr. Emybel M. Alegre, College of Education, Caraga State University 